\title{
Fragilidium duplocampanaeforme sp. nov. (Dinophyceae): A new phagotrophic dinoflagellate from the French Atlantic coast
}

\author{
Elisabeth Nézan ${ }^{\mathrm{a},{ }^{*}}$ and Nicolas Chomérat ${ }^{\mathrm{a}}$
}

\author{
a IFREMER, Laboratoire Environnement et Ressources-Finistère Bretagne-Nord, 13 rue de Kérose, F-29187 \\ Concarneau Cedex-France
}

\begin{abstract}
*: Corresponding author
E. Nézan, Fax: +33 $298 \quad 50 \quad 51$ 02, email address elisabeth.nezan@ifremer.fr
\end{abstract}

\begin{abstract}
:
A new species of the genus Fragilidium, $F$. duplocampanaeforme sp. nov., is described from examinations by LM and SEM. This species has been recorded in summer on the French Atlantic coast, over a number of years. It was never abundant in the plankton and was very often associated with Fragilidium subglobosum, Pyrophacus horologium and also with toxigenic species of the genera Alexandrium and Dinophysis. Phagotrophy of $F$. duplocampanaeforme on Dinophysis prey is shown, and sexual reproduction is suggested by the observation of gamete-like small forms. The size and the peculiar shape of its cells do not correspond to any known taxon, but the plate arrangement fits the genus Fragilidium. The plate formula is Po, Pc, 4', 8", 10c, 6s?, 7m, 2m, 1p. A close examination of the plate morphology reveals an apical closing platelet $\mathrm{Pc}$ and significant differences from known Fragilidium species. Plate ornamentation is complex. A longitudinal fold and an unusual optional pore are seen on the antapical plate $2 m$. Other distinctive morphological features are emphasized which discriminate this new species from others of the genus Fragilidium.
\end{abstract}

Keywords: Atlantic ocean; Dinophyceae; Fragilidium; Fragilidium duplocampanaeforme sp. nov.; Phagotrophy; Taxonomy

\section{Introduction}

The genus Fragilidium Balech ex Loeblich III was erected by Balech (1959) with F. heterolobum as the type species, and was accepted according to the International Code of Botanical Nomenclature after the inclusion of a Latin diagnosis (Loeblich 1965). Balech assigned Goniodoma lacustris Lindemann, 1924 E. Lindemann, Peridineen aus dem goldenen Horn und dem Bosporus, Bot. Arch. 5 (1924), pp. 216-233.Lindemann (1924) to the genus Fragilidium in 1988 and published two papers describing two new species, F. mexicanum Balech (1988) and F. fissile Balech (1990). In 1980, Loeblich included Helgolandinium subglobosum Von Stosch in the genus Fragilidium (Loeblich, 1980). When Von Stosch described the new genus Helgolandinium and species $H$. subglobosum in 1969, he was probably not aware of Balech's recent genus Fragilidium. So, the two genera can be considered as synonyms with Fragilidium as the valid genus (Sournia 1986). At present, this comprises five species. However, it is seldom reported in taxonomic checklists, probably as a consequence of its confusion with other genera, although the mixotrophy of some species has been studied (Hansen and Calado 1999; Jeong et al. 1997; Skovgaard 1996a).

Thanks to the national phytoplankton monitoring network (REPHY), a thecate dinoflagellate has been recorded in Northwestern Atlantic coastal waters of France, during the warm season, since 1990. In July 2006, during an oceanographic cruise (HABIT) on board R/V Thalassa, it was found again and samples have been collected in order to study it by light 
microscopy (LM) and scanning electron microscopy (SEM). Its thecal plate arrangement fitted the genus Fragilidium but the shape of the cells and details of some thecal plates showed it was not identical to any known species. Usually this dinoflagellate was associated with Fragilidium subglobosum and Pyrophacus horologium, as well as with toxigenic species and, dependent on its prey, it could be a vector of unaltered or modified phycotoxins, as suggested later. Thus, a better knowledge of the genus Fragilidium is of considerable importance.

In this paper, the results of a detailed morphological study by both LM and SEM are provided and converge towards the description of a new species.

\section{Materials and methods}

Water and plankton net samples used in this study came from the Northwestern French Atlantic coast. They were collected mainly in July 2006 from $48^{\circ} 07^{\prime} \mathrm{N}, 04^{\circ} 32^{\prime} \mathrm{W}$ to $47^{\circ} 12^{\prime} \mathrm{N}, 02^{\circ} 45^{\prime} \mathrm{W}$ during the HABIT cruise and occasionally through monitoring (Fig. 1). Water temperature and salinity ranged from $16.4^{\circ} \mathrm{C}$ to $18.5^{\circ} \mathrm{C}$ and from 34.8 to 35.2 psu, respectively. Samples were collected from different depths during the cruise and from the surface through the monitoring network. Fresh samples were immediately observed and subsamples were fixed with an acidic Lugol's solution for further examinations.

For light microscopy (LM), living cells were examined under an IX70 Olympus inverted light microscope. Fixed cells were pipetted individually and were placed between a glass slide and a coverslip to study their shape, either under IMT2 Olympus inverted light microscope fitted with film camera or under an IX70 Olympus inverted light microscope equipped with a digital camera. Before dissection, each cell was photographed and measured, using a calibrated micrometer or from photographs. Then, a drop of 5\% sodium hypochlorite solution was added to one side of the coverslip. The coverslip was lightly pressed to expel the cytoplasm and study on the one hand, the thecal plates on the other hand, the cell content using a BX41 Olympus upright light microscope. Film photographs were digitized.

For scanning electron microscopy (SEM), cells were isolated with a capillary pipette and rinsed in deionised water to remove salts and fixative traces. The suspension of isolated cells was then filtered on a polycarbonate membrane filter (Millipore GTTP Isopore, $0.22 \mu \mathrm{m}$ pores) using a syringe and a Swinnex filter holder (Millipore). The membrane covered with cells was deposited on a special device to cage cells (Chomérat and Couté 2008) before dehydration through a graded series of ethanol solutions and critical-point drying. Cells were then 4 coated with gold and observed with a Quanta 200 (FEI, Eindhoven, The Netherlands) scanning electron microscope. Some SEM pictures were presented on uniform background using Adobe Photoshop CS2 (version 9.0.2, Adobe systems, San Jose, CA, USA).

In this paper, the classification of Fensome et al. (1993) is followed and the terminology used for thecal plates is based on the Kofoid system as modified by Balech (1980a).

\section{Results \\ Fragilidium duplocampanaeforme Nézan et Chomérat, sp. nov. Diagnosis}

Cellulae aspectu frontali duplocampanulatae et apicali circulares. Cellularum dimensiones mediae ad magnae. Longitudo : 52-72 $\mu \mathrm{m}$; latitudo : 52-71 $\mu \mathrm{m}$. Epitheca altior quam hypotheca duae similes duarum campanularum inter se basifixarum. Cingulum subaequatorium, profunde excavatum, 0.75 vel duplicato quam latitudine descendens. Sulcus brevis angustusque. Lorica plus minusve scabra cum parvis poris. APC (pori apicali complexio) cum duabus laminis Po et Pc. Tabulatio : Po, Pc, 4',8", 10c, 6s ?, 7"',2"'", 1p. Prima praecingularis lamina (1") cum poro proxime posteriorem marginem. Secunda antapicalis lamina (2'"') cum longitudinali anfracto et posteriore poro fortuito. Chromoplasti fusci numerosi. 
Cells medium to large in size, like two bells stuck together in ventral view, circular in apical view, 52-72 $\mu \mathrm{m}$ long, 52-71 $\mu \mathrm{m}$ wide. Epitheca higher than hypotheca. Cingulum in subequatorial position, descending 0.75-1 times its width. Sulcus short and narrow. Thecal surface more or less rugose with small pores. Apical pore complex APC with two plates Po and Pc. Plate formula: Po, Pc, 4',8",10c, 6s?, 7'",2"', 1p. First precingular plate (1") with a pore near its posterior margin. Second antapical plate (2'"') with a longitudinal fold and an optional posterior pore. Chromoplasts numerous and brown.

Habitat: Marine

Type locality: Concarneau Bay (47 $\left.51^{\prime} \mathrm{N}, 03^{\circ} 57^{\prime} \mathrm{W}\right)$,

Northwest Atlantic Ocean, France

Holotype: Fig. 17. The stub number 07-E9 has been deposited at the National Museum of Natural History (RDDM Department, USM 505)

Isotypes: Figs 18-20

Etymology: Latin duplo, campana and formis, referring to the shape like two bells stuck together.

Cells of Fragilidium duplocampanaeforme sp. nov. are characterized by yellow-brown, elongated and radiating chromoplasts. The nucleus is transversely located at cingulum level (Fig. 2). Their shape looks like two bells stuck together mouth-to-mouth (Figs 3, 4, 9-11, 17- 18 19). They are not dorsoventrally compressed (Figs 5, 6, 20, 23). Size ranges from 52 to $72 \mu \mathrm{m}$ in length (mean $60.9 \mu \mathrm{m}$, s.d. $6.1 \mu \mathrm{m} ; \mathrm{n}=20$ ) and from 52 to $71 \mu \mathrm{m}$ in width (mean $59.4 \mu \mathrm{m}$, s.d. $5.6 \mu \mathrm{m} ; \mathrm{n}$ $=20$ ). The epitheca and the hypotheca are bell shaped because of their outline that is convex near their apex to become concave at the cingulum level (Figs 3, 4, 9-11, 17-19). The hypotheca, shorter than the epitheca, is sometimes marked by an irregular outline (Fig. 12). The cingulum is excavated, subequatorial and descending 0.75-1 times its own width. The sulcus is short and narrow with moderately developed lists (Fig. 24). It does not reach the antapex (Figs 3, 17). The thecal surface is rugose with more or less numerous and unevenly distributed depressions (Fig. 33) not perceivable from the inside (Fig. 34). Small pores $(0.1$ to $0.2 \mu \mathrm{m})$ are situated at the bottom of most of them to form rows, small groups or a network (Figs 32, 33). Thus, the major plates generally do not appear smooth when seen under the light microscope (Figs 14, 15).

The epitheca is composed of the apical pore complex APC (consisting of the apical pore plate Po and the apical closing plate Pc), four apical plates (4') and eight precingular plates (8") (Figs 5,20). The APC is large, irregularly quadrangular and obliquely directed with regard to the median plane. The Po plate is major and quadrangular (Figs 5, 22). Its left side in common with the plate 1 ' is convex, contrary to the others that are straight (Figs 5, 22). This plate is overlapped by all the apical plates (Fig. 21). Many pores are randomly distributed on its surface (Fig. 22). The Pc plate is long, narrow and bent with an anterior end as a crochet's head (Fig. 22). Its left side in contact with the plate Po is sinuous (Fig. 22). This plate has its homologue in the genus Alexandrium (Fukuyo 1985) but also in Pyrophacus with P. steinii (Figure 3 in Pholpunthin et al. 1999) and $P$. horologium (our observations). The apical pore (a.p.) is fishhook shaped with an external thickened border and a dorsal branch more curved at its end (Fig. 21). It is located near the center of the APC. Among the apical plates, the first (1') is six-sided without contact with the first precingular plate 1" (Figs 5, 20). Plates 2' and 3' are pentagonal or hexagonal. Their optional sixth side in common with 6" or 5 " is short (Figs 18, 19). Plate 4' is seven-sided and contacts the plate 2" (Figs 3, 5, 17, 20). Among the precingular plates, the most characteristic is 1" that is four-sided and has a slot ended by a pore (Figs 3, 8, 13, 17, 26-28). It is overlapped by all the adjacent plates, i.e. $2 ", 8 "$ and 4' (Fig. 26) and its shape is roughly trapezoidal (Figs 8, 26-28).

On the hypotheca, the narrowest postcingular plates are 1"' and 7"' (Figs 6, 23). Plate 1"' is tetragonal in shape and longer than wide (Figs 3, 7, 17, 24). It slightly contacts the first cingular plate $\mathrm{C} 1$ and the anterior sulcal plate (S.a.) (Figs 3, 7). Its greater width is posterior (Figs 3, 7, 17). Its right margin bearing the left sulcal list is slightly concave anteriorly to become slightly convex posteriorly (Figs 3, 7, 24). Plate 7'" is the last of the postcingular series. It is posteriorly widened 
with an internal margin bearing a small list (Figs 3, 7, 24). The antapical plates 1"' and 2"'" are characterized by an irregular and rather long side in common (Figs 6, 23, 24). Plate 1"' is asymmetrical and its longest borders are curved (Figs 6, 23, 25). It contacts the sulcus very shortly (Figs 3, 6, 25). The second antapical 2"' is elongated and oblique to the right with a longitudinal fold directed from the left anterior to the right posterior of the plate (Figs 23, 24, 29, 30). The most characteristic feature is the optional presence of a pore located either on the plate boundary 2 "'"/5"' (Fig. 15) or displaced within the plate 2"' and connected to this suture by a groove (Fig. 16). This feature is similar in some Alexandrium species at the posterior sulcal plate level (Balech 1995). Sometimes, the groove is observed without this posterior pore (Figs 30, 31). The intercalary plate $1 \mathrm{p}$ is wide and pentagonal (Fig. 6). The cingulum with lists is formed by ten subequal plates (10c) irregularly porulated. The sulcus consists of six major plates (Fig. 7) but it is possible that minor accessory plates are occluded. The anterior sulcal plate (S.a.) is as high as wide with a convex and reinforced right border and a straight to concave left one. It shows a little posterior sinus and a long and narrow apophysis. The left and right anterior sulcal plates (S.s.a and S.d.a.) are wider than high whereas the S.d.a. finds particularly its homologue in Goniodoma (Balech 1980b) and Alexandrium (Balech 1995). The left posterior sulcal plate (S.s.p.) is high and anteriorly widened whereas the right posterior sulcal plate (S.d.p.) is very small and easily hidden by the right sulcal list. The posterior sulcal plate (S.p.) is very short, five sided (Figs 3, 7) and scarcely contacts the 1'"' (Figs 3, $6,25)$.

Vegetative cells of $F$. duplocampanaeforme have been observed during the summers 1990, 1991, 1993 and 1994, in low abundances in water samples of the monitoring network (below $10^{3}$ cells $\mathrm{L}^{-1}$ ), in July 2006 in plankton net samples during the cruise and exceptionally in July 2007 in an occasional plankton net monitoring sample. They were most often associated with toxigenic dinoflagellates of the genera Alexandrium as A. andersonii Balech, A. ostenfeldii (Paulsen) Balech et Tangen and Dinophysis as D. acuminata Claparède et Lachmann. And, in one sample of 1993, several ingested cells of $D$. acuminata have been extracted from the protoplasm of a large cell of $F$. duplocampanaeforme (Figs 35-37). Moreover, from another very distorted cell, unidentifiable before dissection, one complete cell of D. caudata was expelled, proving the engulfment of large preys and the phagotrophic behavior of $F$. duplocampanaeforme (Figs 38-40). In the same time, the thecal plates of these two specimens have ensured the correct identification of $F$.

duplocampanaeforme. Lastly, rare specimens of a small form (width $26-28 \mu \mathrm{m} ; \mathrm{n}=2$ ) have been noticed in the sample of July 2007 (Fig. 41). Their plate arrangement fitted with the genus

Fragilidium though the ventral plate with the pore was directly connected to the APC (Figs 42-43), but, in spite of this discrepancy, their general shape was very close to the vegetative cells of $F$. duplocampanaeforme.

\section{Discussion}

Some differences in the plate formula from one species to another occur in the genus Fragilidium Balech ex Loeblich III 1965 (Table 1). F. lacustre is missing in this table because its plate formulation is incomplete (Lindemann 1924). The epithecal plate tabulation of $F$. duplocampanaeforme is identical to $F$. mexicanum and $F$. fissile, but it differs from $F$. heterolobum and $F$. subglobosum that have been described with 9 precingular plates ("). In fact, in $F$. heterolobum, Balech (1959) has found 8 or 9 precingular plates, depending whether or not one of them appeared divided into two plates. As to F. subglobosum, the 9" plate has been considered as a very small plate, adjacent to plate 1" (Von Stosch 1969), while, in French specimens, it is only the lower part of plate 1", below the slot and the pore (our observations in SEM). Hence, it does not correspond to a true plate (Table 1). Otherwise, the interpretation of some plates of the furrows can also explain some tabular disparities. So, the platelet at the right end of the cingulum that extends into the sulcus of $F$. duplocampanaeforme is considered as the right anterior sulcal plate (S.d.a.), as in F. mexicanum and F. fissile, while it is described as the cingular plate $\mathrm{C} 12$ or the transitional 
plate $\mathrm{t}$ in $F$. heterolobum or $F$. subglobosum, respectively (Table 2). On the hypotheca, the right perisulcal plate is the last of the postcingular series. In spite of its position, it is considered as plate 7"' in all Fragilidium species, though Balech (1990) had raised a doubt about it. In addition, the posterior plate that does not touch the furrows is an intercalary (after Balech 1980a) and not an antapical (Table 2). From this interpretation, the result is that the hypothecal plate tabulation of $F$. duplocampanaeforme is 7'",2'"', $1 \mathrm{p}$ as in $F$. heterolobum, F. mexicanum and $F$. fissile. And because of the different interpretation of the antapical plates by Von Stosch, the tabulation of $F$. subglobosum is 7"',3"', 0p (Table 1). Actually, the pattern is the same for all Fragilidium species. On the epitheca, the platelet Pc is rarely seen. It is very narrow and the longitudinal boundary between Pc and Po is only perceivable in SEM. Although it appears in the plate formula of the generic diagnosis of Fragilidium (Steidinger et Tangen 1997), this plate has only been reported in F. heterolobum before (Plate 4, Figure B in Steidinger et Tangen 1997). The APC and plate 1" are variable in shape probably as a consequence of their overlap by all adjacent plates. A similar variation has been drawn for F. mexicanum and F. fissile (Balech 1988, 1990).

A comparison of some morphological features of Fragilidium duplocampanaeforme sp. nov. with the other Fragilidium species is provided in Table 2. F. lacustre is absent in this table because some features are missing in the description of Lindemann (1924). Cells of $F$. duplocampanaeforme are large with a large size range and, together with their peculiar outline, they are distinctive from those of the previously recognized Fragilidium species. F.

duplocampanaeforme differs also from the other species by its complex plate ornamentation, not only marked by small pores. In terms of plate arrangement, $F$. duplocampanaeforme is more closely related to $F$. mexicanum and $F$. heterolobum. But, notwithstanding the 1 " is four sided, the shape of the apical and sulcal plates, with the S.a. mainly, allows these three species to be distinguished. Otherwise, this is the first time that a Fragilidium species is described with a second antapical plate (2'"') marked both by a longitudinal fold and sometimes by a pore, sometimes a groove, or both. Besides, this pore can be found within the plate or on the suture with the postcingular plate 5 '". For all these reasons, $F$. duplocampanaeforme is distinct from the other described Fragilidium species.

Homologies have been underlined at the time of the description of some thecal plates, which means that the genus Fragilidium has affinities sometimes with Pyrophacus, sometimes Alexandrium and sometimes Goniodoma. Although Fensome et al. (1993) considered that these genera are close enough to belong to the same family, a molecular study is needed to demonstrate the extent of these affinities. However, we did not succeed yet in determining DNA sequences of $F$. duplocampanaeforme to undertake a such approach.

The presence of chromoplasts and the phagotrophy observed in $F$. duplocampanaeforme show the mixotrophic behaviour of this species. This is a new reported case of feeding by Fragilidium upon dinoflagellates, after $F$. mexicanum grazing on Alexandrium prey (Balech 1988), F. subglobosum on Ceratium spp. (Skovgaard 1996b), F. cf. mexicanum on Protoperidinium cf. divergens (Jeong et al. 1997) or Fragilidium sp. on Dinophysis acuminata (Fukuyo in Jacobson 1999). But the case of the engulfment of a prey as large as Dinophysis caudata, possessing a very developed antapical projection, shows that the theca of $F$. duplocampanaeforme is able to remain intact although the plates separate as reported by Hansen and Calado (1999). Previously, the complete ingestion of an elongate, horned thecate cell of Ceratium by F. subglobosum has been mentioned by Skovgaard (1996b), with dissolution of the prey theca during the process of engulfment. Here, the observation of the complete theca of Dinophysis within the protoplasm of $F$. duplocampanaeforme suggests another mechanism of digestion. Otherwise, the grazing pressure of Fragilidium on toxic Alexandrium or Dinophysis could transfer toxins potentially transformed by enzymatic activity to the grazer, as suggested for some mixotrophic taxa (Escalera et al. 2007). 
Concerning the small form, a ventral plate fused with the APC has also been reported fromone individual of $F$. heterolobum (Balech 1959). Since individuals smaller than vegetative cells have already been observed in cultures of Pyrophacus and have been interpreted as gametes (Montresor and Marino 1994; Pholpunthin et al. 1999), we hypothesize that these small specimens of $F$. duplocampanaeforme could be a sign of sexual reproduction in natural conditions, but this still needs to be verified.

The description of this new species contributes to a better knowledge of the genus Fragilidium, rarely cited though its taxonomy has been particularly studied by Von Stosch (1969) and Balech up to 1990. Since that date, no Fragilidium species has been describeduntil the present study. A molecular analysis is needed, not only to ascertain the systematic position of the genus Fragilidium, but also to discriminate unequivocally between the different species.

\section{Acknowledgements}

Thanks to Prof. Alain Couté for the Latin diagnosis and to Philippe Crassous for technical assistance in SEM observations. The authors acknowledge the support of the European Commission (HABIT/GOCE-CT-2005-003932), scientists and crew of R/V Thalassa and especially Drs B. Reguera, R. Raine and P. Gentien.

\section{References}

Balech, E., 1959. Two new genera of dinoflagellates from California. Biol. Bull. 116, 195-203.

Balech, E., 1980a. On thecal morphology of Dinoflagellates with special emphasis on circular and sulcal plates. An. Centro Cienc. Del Mar y Limnol. Univ. Nal. Auton. Mexico. 7, 57-68.

Balech, E., 1980b. El género Goniodoma Stein (Dinoflagellata). Lilloa 35 «1979» (2), 97-109 incl. pl. 1-2.

Balech, E., 1988. Una especie nueva del género Fragilidium (Dinoflagellata) de la bahía de Chamela, Jalisco, México. An. Inst. Biol. UNAM 58, 479-486.

Balech, E., 1990. Four new dinoflagellates. Helgol. Meeresunters. 44, 387-396.

Balech, E., 1995. The genus Alexandrium Halim (Dinoflagellata). Sherkin Island Marine Station, Sherkin Island, Co. Cork, Ireland.

Chomérat, N., Couté, A., 2008. Protoperidinium bolmonense sp. nov. (Peridiniales, Dinophyceae), a small dinoflagellate from a brackish and hypereutrophic lagoon (South of France). Phycologia 47(3), in press.

Escalera, L., Pazos, Y., Moroño, A., Reguera, B. 2007. Noctiluca scintillans may act as a vector of toxigenic microalgae. Harmful algae 6, 317-320.

Fensome, R.A., Taylor, F.J.R., Norris, G., Sarjeant, W.A.S., Wharton, D.I., Williams, G.L., 1993. A classification of living and fossil dinoflagellates. Sheridan Press, Hanover.

Fukuyo, Y., 1985. Morphology of Protogonyaulax tamarensis (Lebour) Taylor and Protogonyaulax catenella (Whedon and Kofoid) Taylor from Japanese coastal waters. Bull. Mar. Sci. 37, 529-537. 
Hansen, P.J., Calado, A.J., 1999. Phagotrophic mechanisms and prey selection in free-living dinoflagellates. J. Eukaryot. Microbiol. 46, 382-389.

Jacobson, D.M., 1999. A brief history of dinoflagellate feeding research. J. Eukaryot. Microbiol. 46, 376-381.

Jeong, H.J., Lee, C.W., Yih, W.H., Kim, J.S., 1997. Fragilidium cf. mexicanum, a thecate mixotrophic dinoflagellate which is prey for and a predator on co-occurring thecate heterotrophic dinoflagellate Protoperidinium cf. divergens. Mar. Ecol. Prog. Ser. 151, 29911305.

Lindemann, E., 1924. Peridineen aus dem goldenen Horn und dem Bosporus. Bot. Arch. 5, 216233.

Loeblich, A.R.III., 1965. Dinoflagellate nomenclature. Taxon 14, 15-18.

Loeblich, A.R.III., 1980. Dinoflagellate nomenclature. Taxon 29, 321-324.

Montresor, M., Marino, D., 1994. New observations on the life cycle of Pyrophacus horologium Stein (Dinophyceae). Bol. Soc. Adriatica Sci. 125, 261-268.

Pholpunthin, P., Fukuyo, Y., Matsuoka, K., Nimura, Y., 1999. Life history of a marine dinoflagellate Pyrophacus steinii (Schiller) Wall et Dale. Botanica Marina 42, 189-197.

Skovgaard, A., 1996a. Mixotrophy in Fragilidium subglobosum (Dinophyceae): growth and grazing responses as functions of light intensity. Mar. Ecol. Prog. Ser. 143, 247-253.

Skovgaard, A., 1996b. Engulfment of Ceratium spp. (Dinophyceae) by the thecate photosynthetic dinoflagellate Fragilidium subglobosum. Phycologia 35, 400-409.

Sournia, A., 1986. Atlas du Phytoplancton Marin. Volume I : Introduction, Cyanophycées, Dictyochophycées, Dinophycées et Raphidophycées, Editions du Centre National de la Recherche Scientifique, Paris.

Steidinger, K.A., Tangen, K., 1997. Dinoflagellates. In: Tomas, C.R. (Ed.), Identifying Marine Phytoplankton. Academic Press, New York, pp. 387-584.

Von Stosch, H.A., 1969. Dinoflagellaten aus der Nordsee II. Helgolandinium subglobosum gen. et spec. nov. Helgol. wiss. Meeresunters. 19, 569-577. 


\section{Legends}

Fig. 1. Locations where Fragilidium duplocampanaeforme sp. nov. was observed (open circles = monitoring stations, filled circles $=$ cruise stations).

Fig. 2. Fragilidium duplocampanaeforme sp. nov., light micrograph of a living cell. $\mathrm{n}=$ nucleus (outlined by dots). Scale bar $=20 \mu \mathrm{m}$.

Figs 3-8. Fragilidium duplocampanaeforme sp. nov., line drawings showing morphology and arrangement of thecal plates. 3, Ventral view. 4, Dorsal view. 5, Apical view. 6, Antapical view. 7, Sulcal area. $\mathrm{Sa}=$ anterior sulcal, $\mathrm{Ssa}=$ left anterior sulcal, $\mathrm{Sda}=$ right anterior sulcal, $\mathrm{Ssp}=$ left posterior sulcal, $\mathrm{Sdp}=$ right posterior sulcal, $\mathrm{Sp}=$ posterior sulcal. 8, Plate 1" from four different specimens. Scale bars $=20 \mu \mathrm{m}$ except for Figs 7-8.

Figs 9-16. Fragilidium duplocampanaeforme sp. nov. cells and theca details viewed with LM. 912, Cells fixed with Lugol's solution. 9, Ventral view. 10, Dorsal view. 11, Lateral view. Note the orientation of the APC (arrowheads). 12, A cell with a marked posterior lobulation. 13, An empty individual (theca). Note plates separated from each other and the ventral pore (arrowhead). 14-16, A fragment of the hypotheca. Note the position of the posterior pore (arrowheads). Scale bars $=20$ $\mu \mathrm{m}$ in Figs 9-13 and $10 \mu \mathrm{m}$ in Figs $14-16$.

Figs 17-25. Fragilidium duplocampanaeforme sp. nov., scanning electron micrographs of the surface morphology. 17, Ventral view. 18, Dorsal view. Note the contact between 3' and 5" (arrowhead). 19, Right lateral view. Note the contact between 2' and 6" (arrowhead). 20, Apical view. 21, Detail of the apical pore complex (APC) with the apical pore (ap, black arrowhead) and the adjacent plates. Solid white arrows indicate directions of plate overlap. 22, Detail of the apical pore complex (APC) with the plates Po and Pc (black arrow). Note the suture between Po and Pc (white arrows). 23, Antapical view. 24, Detail of some perisulcal 10 plates. 25, Detail of the 1"' in relation to the posterior sulcal plate (S.p.). Scale bars $=20 \mu \mathrm{m} 11$ in Figs 17-20, 23 and $5 \mu \mathrm{m}$ in Figs 21-22, 24-25.

Figs 26-34. Fragilidium duplocampanaeforme sp. nov., scanning electron micrographs of the surface morphology. 26, First precingular plate (1") and its adjacent plates. Solid arrows indicate directions of plate overlap. 27-28, Detail of the 1" and its pore seen from the inside in Fig. 28. 2931 , Detail of the second antapical plate (2'"') that is in reverse position in Fig. 31. The groove in Figs 30 and 31 is shown by a black arrowhead. 32-34, Detail of the thecal surface. 32, Pores in rows or in small groups. 33, Depressions with pores at bottom. 34, Surface seen from the inside. Scale bars $=5 \mu \mathrm{m}$ in Figs 26-32 and $2 \mu \mathrm{m}$ in Figs 33-34.

Figs 35-40. Fragilidium duplocampanaeforme sp. nov., light micrographs of phagotrophic cells. 35, A large cell fixed with Lugol's solution and containing cells of Dinophysis acuminata. 36-37, Dissection of the same specimen. 36, First step with release of the cell content. Note the Fragilidium duplocampanaeforme protoplasm (Fp), an open cell of Dinophysis acuminata with protoplasm (Dp) partly outlined by dots and a visible part of the theca (arrowhead). 37, Second step with release of the protoplasm (Dp) and valves (Dv) of a cell of Dinophysis acuminata from the Fragilidium duplocampanaeforme cell. 38, A distorted cell fixed with Lugol's solution and containing a cell of Dinophysis caudata. 39-40, Dissection of the same specimen. 39, First step with release of the cell content. Note the presence of a cell of Dinophysis caudata (outlined by dots) emerging out of the protoplasm (Fp). 40, Second step with release of the open cell of $D$. caudata (Dp indicates the protoplasm and arrowhead points to the visible part of the theca) from the Fragilidium protoplasm. Scale bars $=20 \mu \mathrm{m}$. 
Figs 41-43. Light micrographs of a small form of Fragilidium duplocampanaeforme sp. nov., assumed to be a gamete. 41, Cell fixed with Lugol's solution. 42, Theca. Note the ventral pore (arrowhead). 43, Displayed thecal plates. Note the ventral plate (arrow) connected to the APC 10 (arrowhead). Scale bars $=20 \mu \mathrm{m}$. 
Table 1. Plate formulation of Fragilidium campanaeforme sp. nov. and other Fragilidium species including Helgolandinium subglobosum.

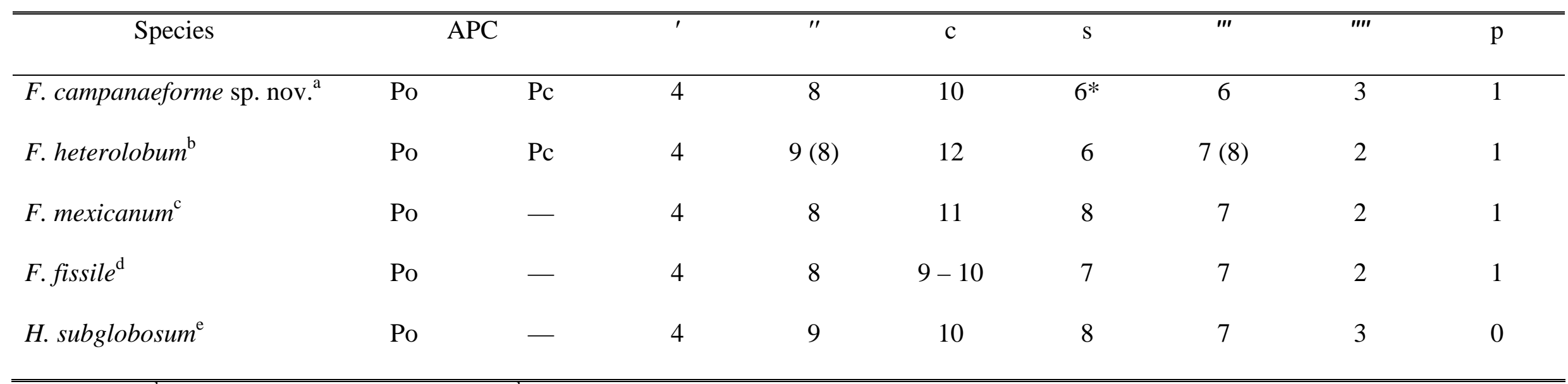

${ }^{\mathrm{a}}$ this study; ${ }^{\mathrm{b}}$ Balech (1959); ${ }^{\mathrm{c}}$ Balech (1988); ${ }^{\mathrm{d}}$ Balech (1990a); ${ }^{\mathrm{e}}$ Stosch (1969).

Abbreviations used: $\mathrm{APC}=$ apical pore complex, $\mathrm{Po}=$ apical pore plate, $\mathrm{Pc}=$ apical closing plate,$-=$ not observed

* At least 6 sulcal plates 
Table 2: Comparaison of some morphological features and plate interpretation of Fragilidium campanaeforme sp. nov. with other Fragilidium or Helgolandinium species.

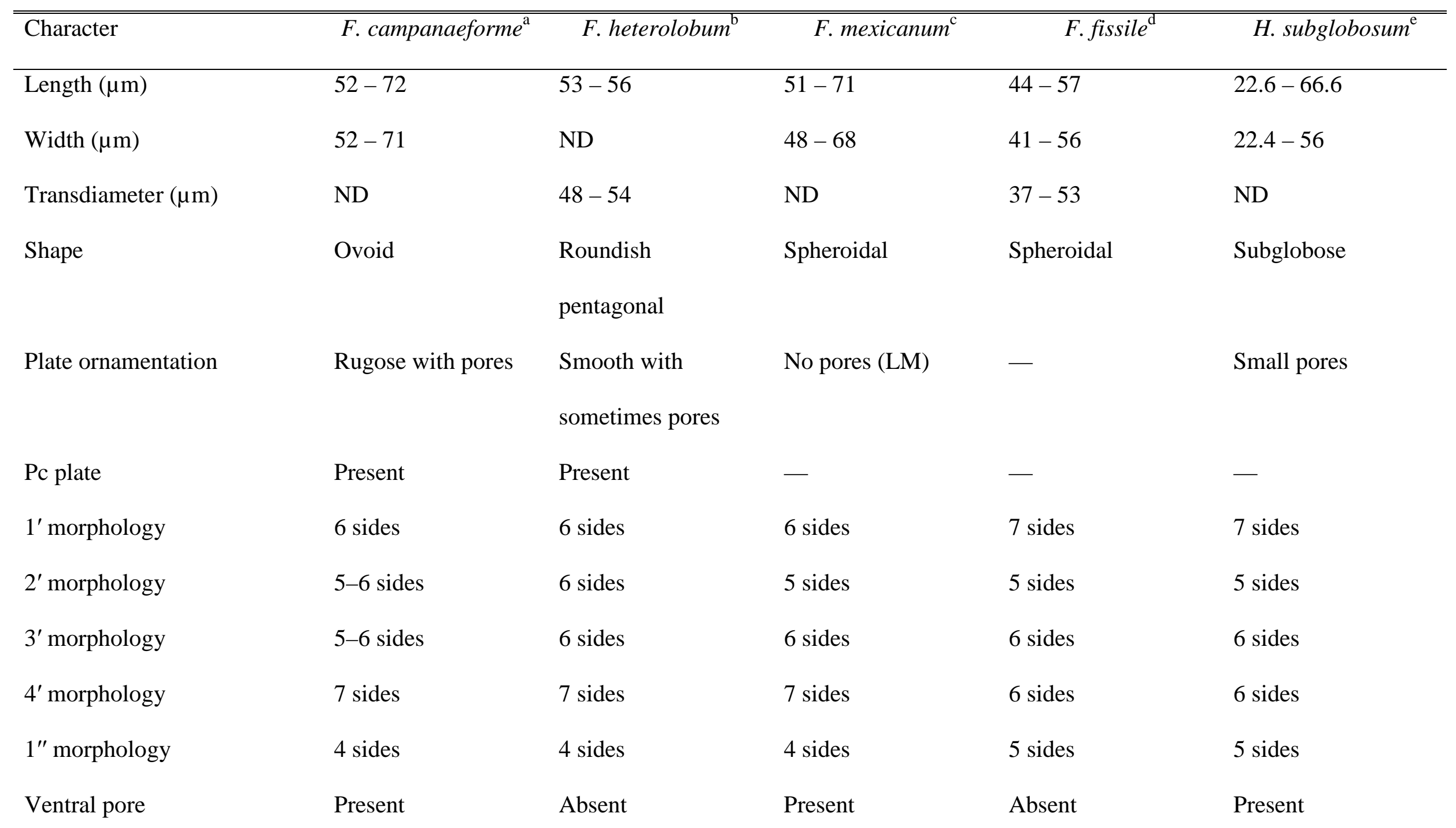




\begin{tabular}{|c|c|c|c|c|c|}
\hline $2^{\prime \prime}$ morphology & 5 sides & 5 sides & 5 sides & 4 sides & 4 sides \\
\hline Contact between $1^{\prime}$ and 1" & Absent & Absent & Absent & Present & Present \\
\hline Contact between $4^{\prime}$ and $2^{\prime \prime}$ & Present & Present & Present & Absent & Absent \\
\hline $1^{\prime \prime \prime}$ morphology & Narrow-tetragonal & Narrow & Narrow-tetragonal & Narrow-tetragonal & Wide-quadrangular \\
\hline Contact between $1^{\prime \prime \prime \prime}$ and $2^{\prime \prime \prime \prime}$ & Sinuous and long & $\begin{array}{l}\text { Sinuous and rather } \\
\text { long }\end{array}$ & $\begin{array}{l}\text { Straight and rather } \\
\text { short }\end{array}$ & Straight and short & $\begin{array}{l}\text { Rather straight and } \\
\text { long }\end{array}$ \\
\hline Optional pore on $2^{\prime \prime \prime \prime}$ & Present & - & - & - & - \\
\hline Right perisulcal plate & As the $3 " ' "$ & As the 7"' & As the 7"' & As the 7"' & As the 7"' \\
\hline $\begin{array}{l}\text { Posterior plate without } \\
\text { contact with the furrows }\end{array}$ & As an intercalary & As an intercalary & As an intercalary & As an intercalary & As an antapical \\
\hline $\begin{array}{l}\text { Transitional plate at the end } \\
\text { of the cingulum }\end{array}$ & As the S.d.a. & As the cingular $\mathrm{C}_{12}$ & As the S.d.a. & As the S.d.a. & As a transitional $\mathrm{t}$ \\
\hline S.a. morphology & Height $\cong$ width & ND & Height $<$ width & ND & ND \\
\hline S.p. morphology & Short & Short & Rather small & High & Long \\
\hline
\end{tabular}

"a this study; ${ }^{b}$ Balech (1959); ${ }^{\mathrm{c}}$ Balech (1988); ${ }^{\mathrm{d}}$ Balech (1990a); ${ }^{\mathrm{e}}$ Stosch (1969).

Abbreviations used: $\mathrm{LM}=$ light microscopy,$-=$ not observed, ND $=$ no data 


\section{Figures}

$4^{\circ} \mathrm{W}$

$2^{\circ} \mathrm{W}$

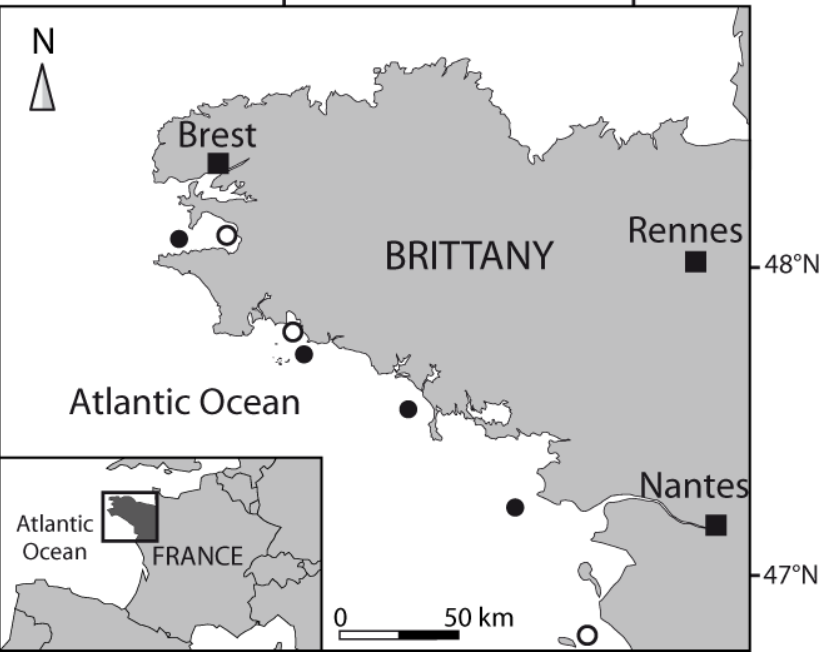

Fig. 1

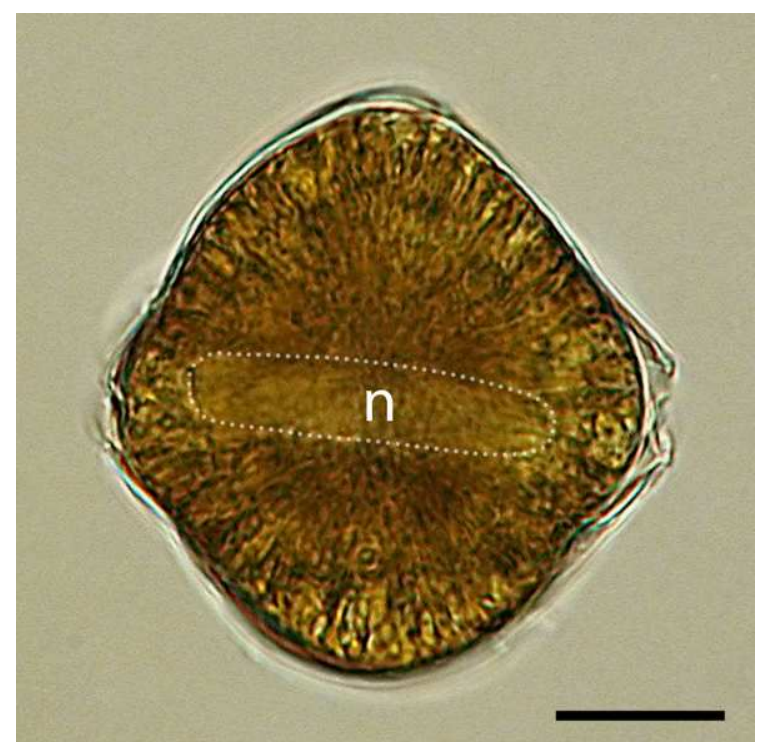

Fig. 2 


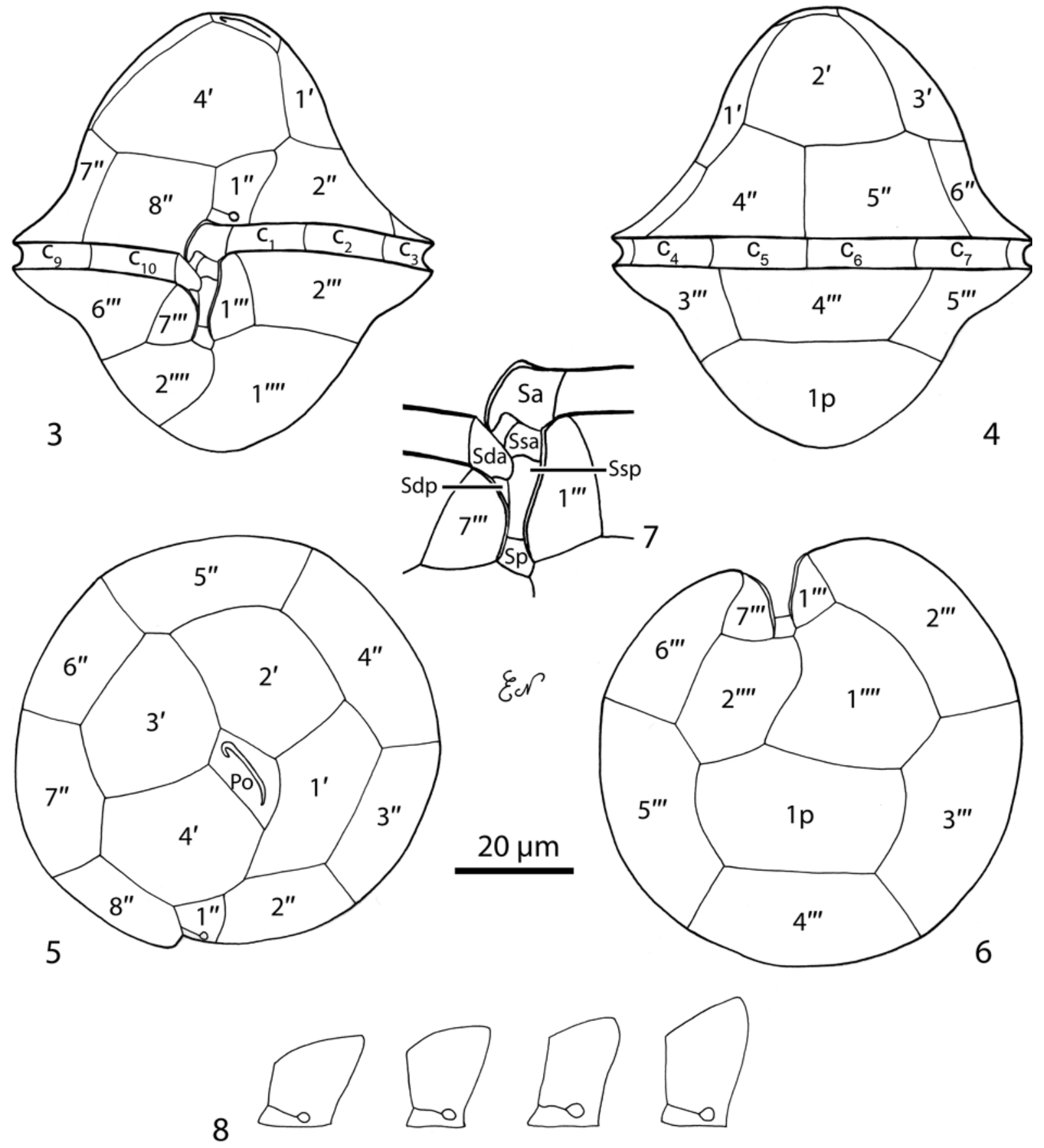

Figs 3-8 

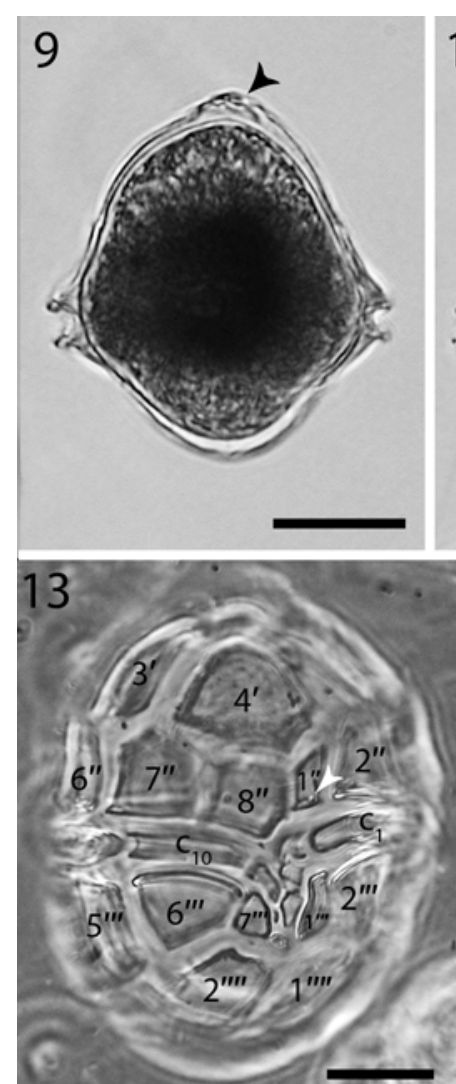

Figs 9-16
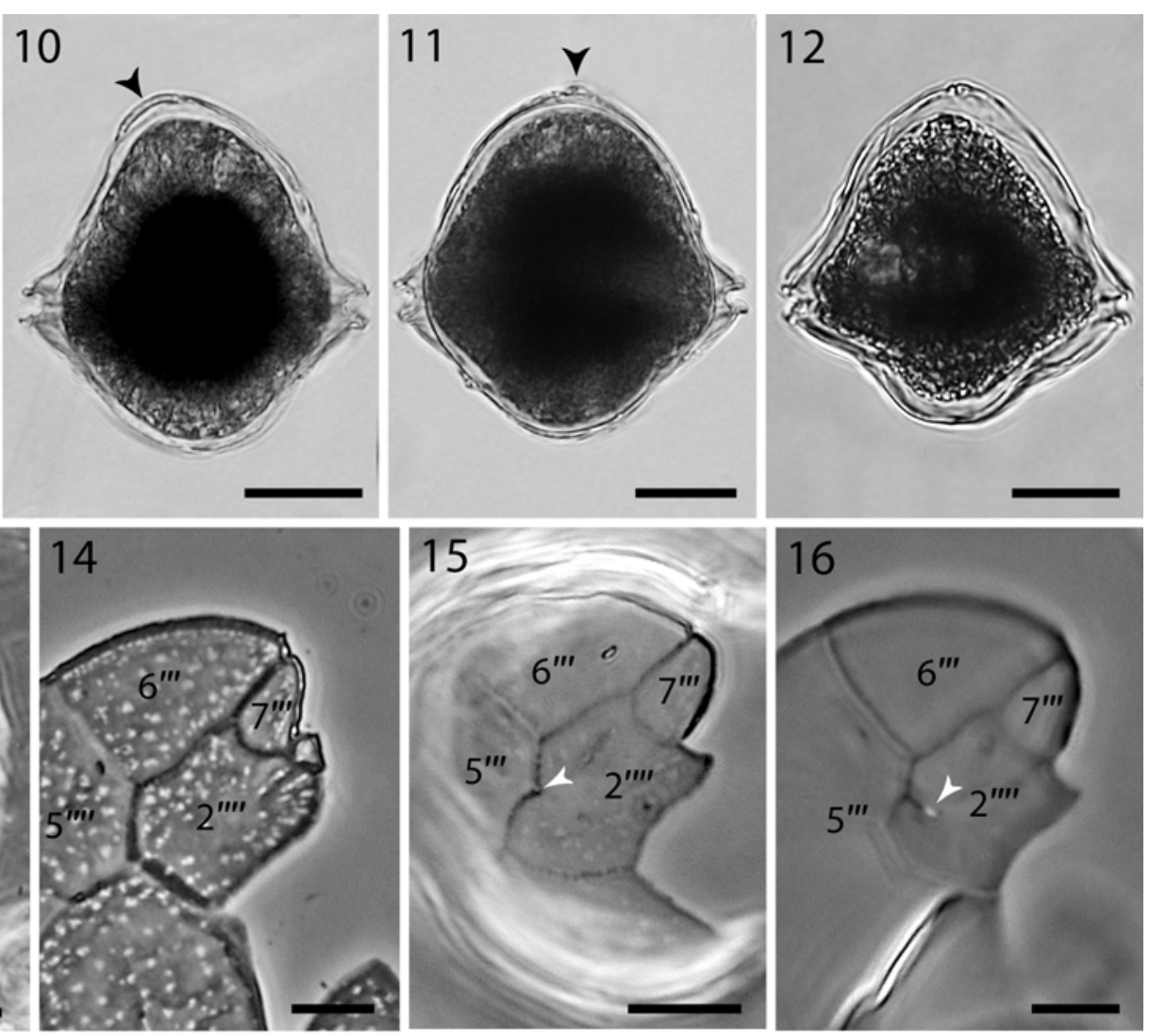

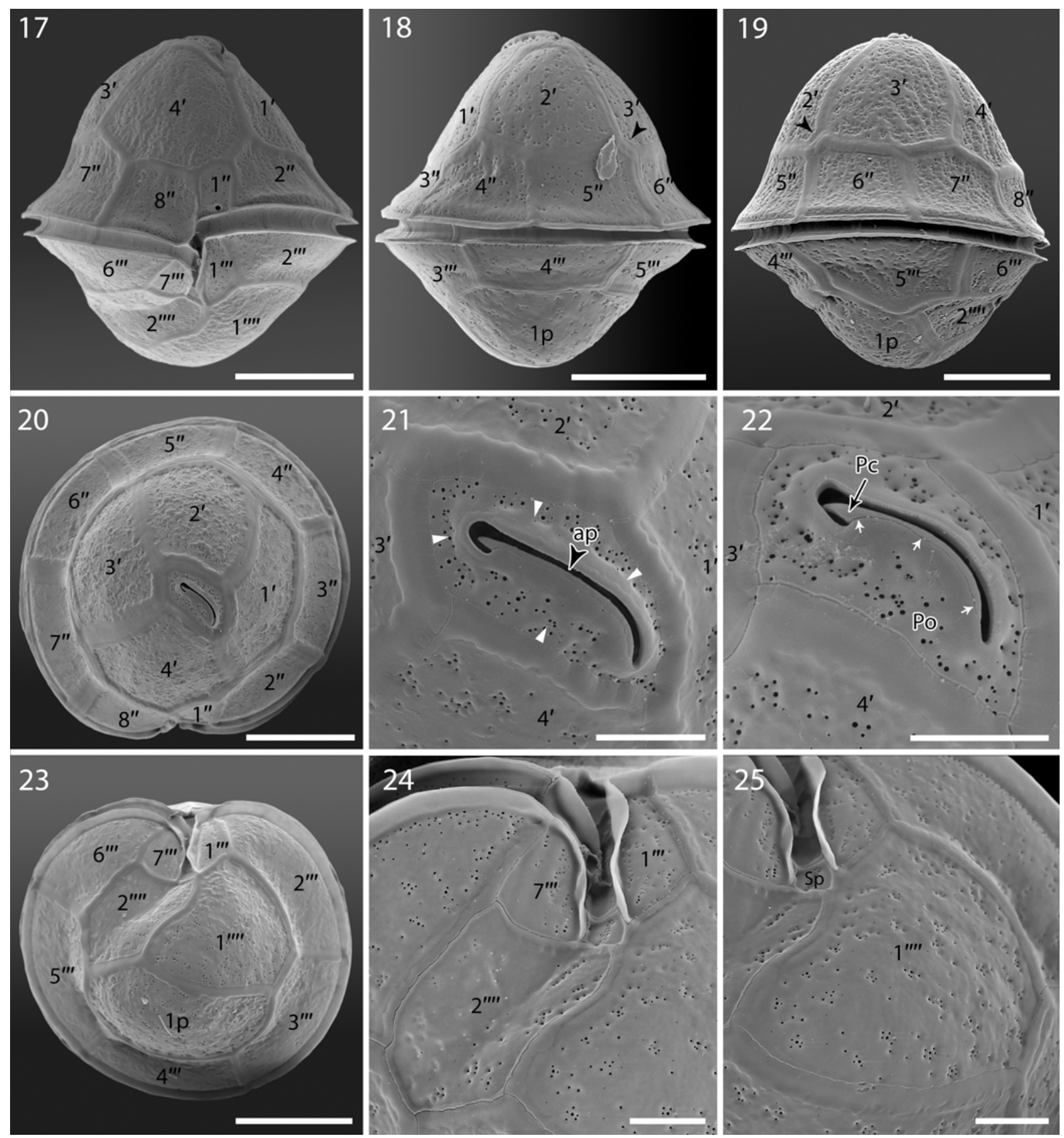

Figs 17-25 

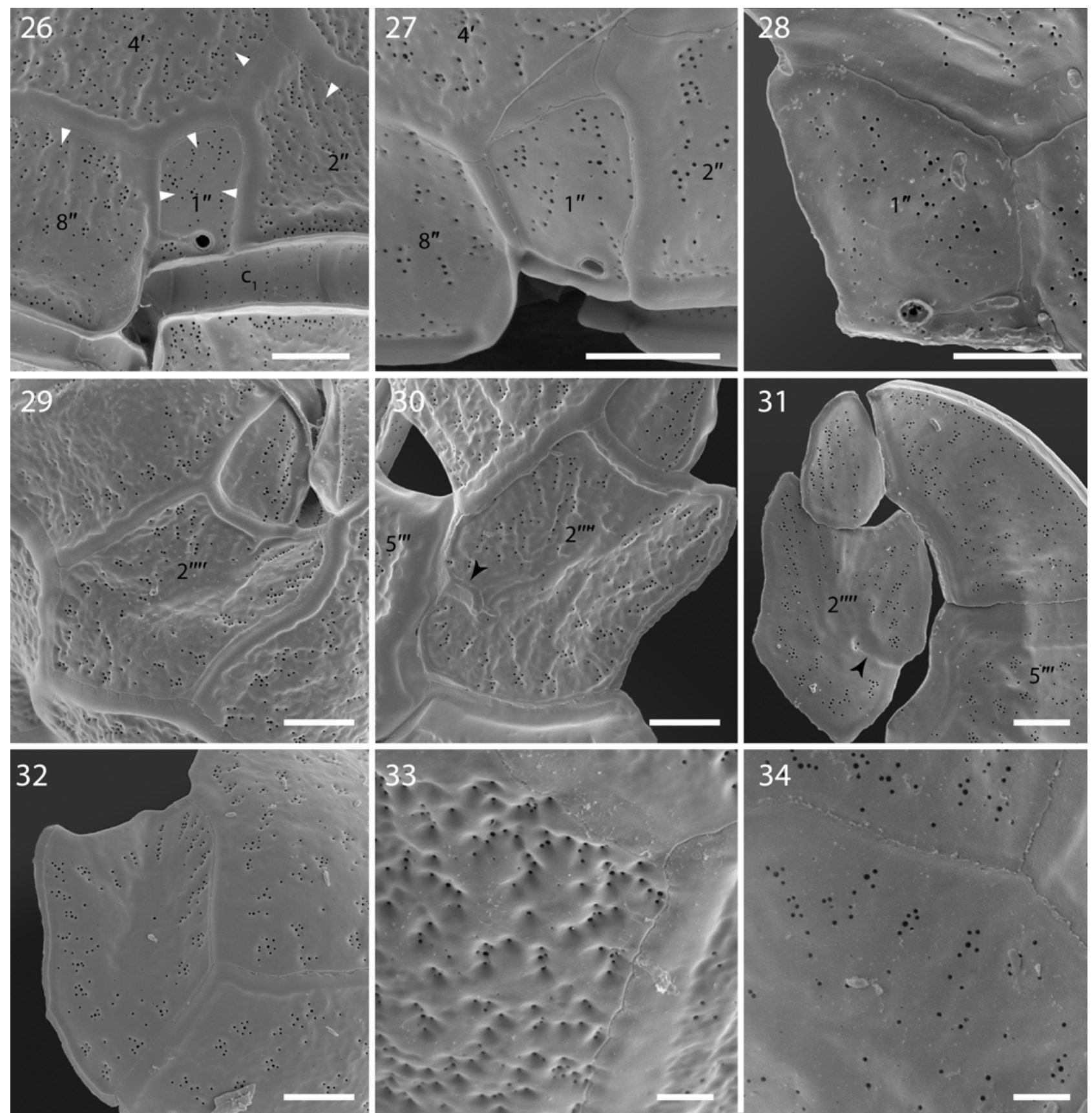

Figs 26-34 

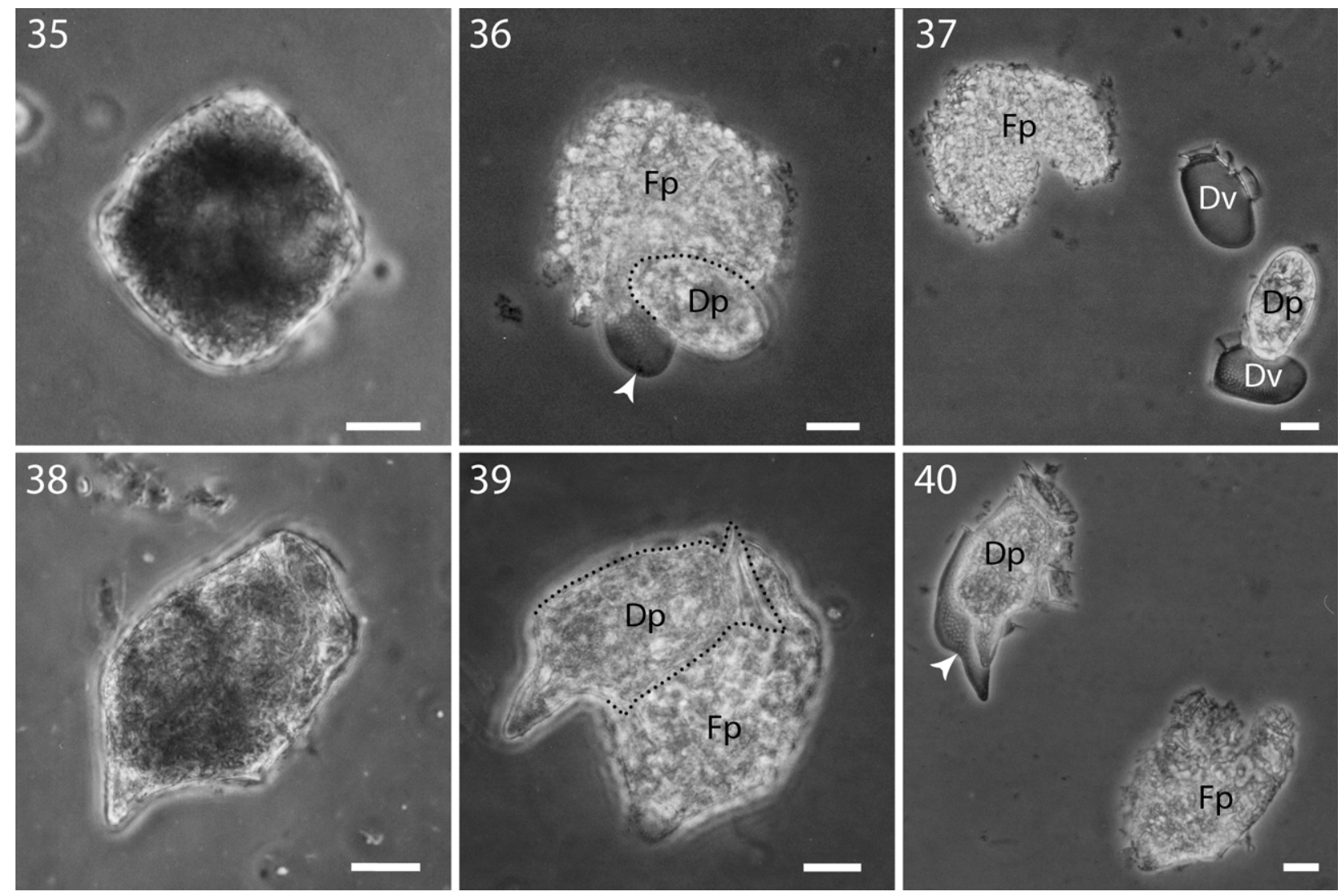

Figs 35-40 


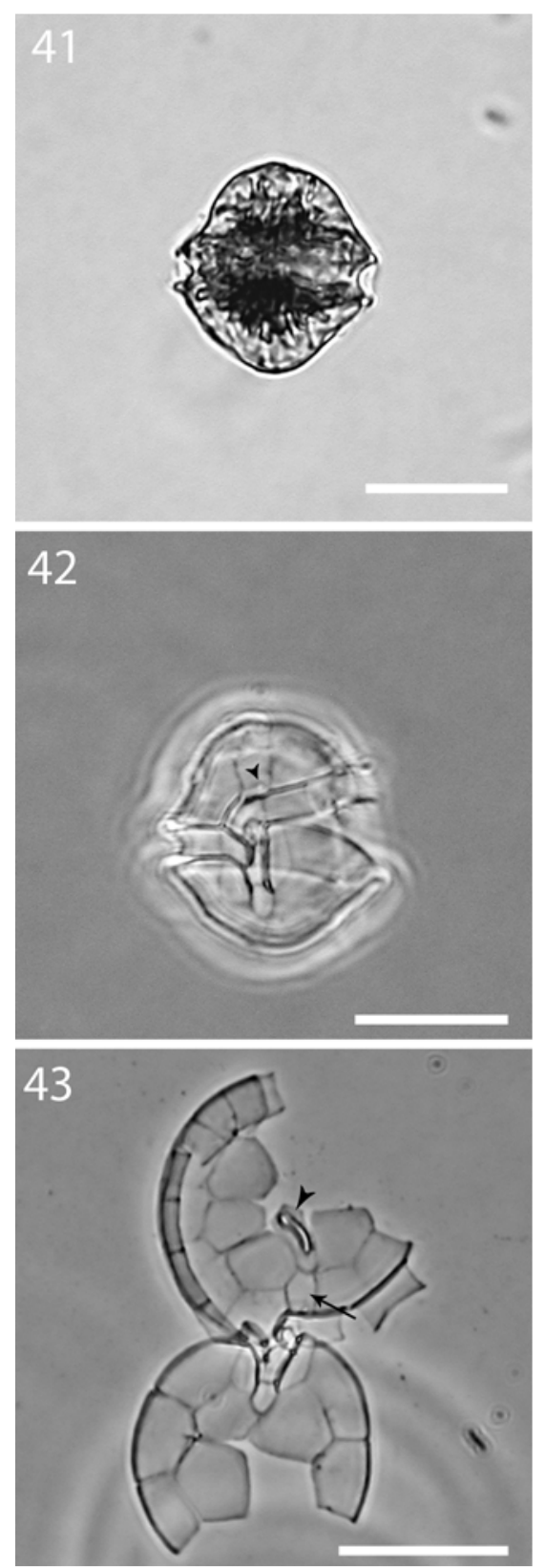

Figs 41-43 